\title{
THE ESSENTIAL OIL CONTENTS OF JERINGAU (Acorus calamus L.) RHIZOMES AND THEIR ANTIFUNGAL ACTIVITY AGAINST Candida albicans
}

\author{
Wiwik Susanah Rita ${ }^{1}$, Retno Kawuri ${ }^{2}$, I Made Dira Swantara ${ }^{1}$ \\ ${ }^{1}$ Chemistry Department, Faculty of Mathematic and Natural Sciences, Universitas of Udayana \\ ${ }^{2}$ Biology Department, Faculty of Mathematic and Natural Sciences, Universitas of Udayana \\ wiwiksr@yahoo.com; susanah.rita@unud.ac.id
}

\begin{abstract}
Acorus calamus L. rhizome was trusted having antibacterial activity. This study aimed to identify the compounds in the Acorus Calamus L. rhizomes essential oils and to recognize the antifungal activity of the oils against Candida albicans. The extraction of essential oils from rhizome was carried out by steam distillation technique. Identification of compounds in the oils was conducted by Gas ChromatographyMass Spectroscopy (GCMS), while the antifungal test against Candida albicans was done by well diffusion method. Extraction of $10 \mathrm{~kg}$ of rhizomes produced $16.53 \mathrm{~mL}$ essential oil with a yield of $0.1653 \%(\rho=1.066)$, the oil was brownish yellow and very flavorful. GC-MS analysis showed that the essential oil contained 11 compounds, they are (E)-3,7 dimethyl-1,3,6-Octatriene (trans- $\beta$-Ocimene) (3,73\%), linalool $(1,07 \%), \beta$-elemene $(1,15 \%)$, trans methyl isoeugenol $(7,68 \%)$, shyobunon $(15,74 \%)$, bicyclogermakren $(0,93 \%)$, dehidroxy-isocalamendiol $(2,61 \%), \alpha$-calacorene $(3,34 \%)$, euasarone $(26,84)$, cis-asarone $(18,62 \%)$; dan trans- asarone $(18,29 \%)$. Antifungal activity test showed that the growth and biomass inhibition of $C$. albicans increased with the increase of the oil concentration. Minimum Inhibitory Concentration (MIC) of essential oil toward C. albicans was $1 \%$ with the inhibition of $7.83 \mathrm{~mm}$.
\end{abstract}

Keywords: Essential oils, Acorus calamus L, Candida albicans

\section{INTRODUCTION}

The less clean environment is a very good place for breeding of disease-causing pathogens such as fungi. Fungal pathogens such as Candida albicans cause opportunistic infections called candidiasis of the skin, mucosa, and organs in humans. C. albicans often infect the mouth or vagina, but when the host has a good immune system, $C$. albicans will not result in infection and live normally in the human oral cavity [4]. Disease control efforts have been conducted, especially the use of chemical drugs, but this is likely to cause resistance. Therefore we need a natural material that is relatively safe plant material containing secondary metabolites, as the active ingredient. One of the plants as controlling fungus is Jeringau (Acorus calamus $\mathrm{L}$.) the rhizomes and leaves of jeringau are used as a medicinal plant.

Traditionally, Jeringau was widely used as a medicine for skin and abdominal pain. Jeringau rhizome was useful as a spasmolytic, carminative, and useful for sedation, digestive, sedative, increase appetite, tonic, antiinflammatory, relieve nasal congestion, and antiseptic ingredients [8]. Pakasi and Salaki (2013) reported that Jeringau rhizome contains essential oils, saponins, and flavonoids [5]. Phongpaichit et al. (2015) reported that the methanol extract of the rhizome Jeringau active as inhibitors of growth of filamentous fungi (Microsporum gypseum, Trichophyton rubrum, and Penicillium marneffei) [6]. Venskutonis and Dagilyte (2003) reported that the essential oil content of dry rhizome of Jeringau, collected in Lithuania was $1.20 \pm 0.12 \%$, while the leaves ranged from 0.56 to $1.01 \%$ depending on the vegetation period. $\delta$ asarone [(Z) -asarone] was the main constituent in the leaves (from 27.4 to $45.5 \%$ ), whereas the main compound of the rhizomes was acorenone (20.86\%) followed by isocalamendiol (12.75\%) [10].

Because the jeringau rhizome contain essential oils and have activity as inhibitors of microbial growth, it is necessary to identify compounds in the oils of Jeringau rhizome collected in Bali and test the antifungal activity of essential oils against Candida albicans.

\section{MATERIALS AND METHODS}

\section{A. Materials}

The plant material used was the rhizome of Jeringau (Acorus calamus L.) collected in Bali. Bioassay material was $C$. albicans obtained in the Microbiology Laboratory, Department of Biology, University of Udayana, Chemicals used in this study were sodium chloride $(\mathrm{NaCl})$, calcium chloride $\left(\mathrm{CaCl}_{2}\right)$ anhydrous, glucose, ethanol $70 \%$, sterile distilled water, Nutrient Agar, and tween-80.

\section{B. Instruments}

The instrument used in this study was a laminar flow cabinet, spayer, aluminum foil, petri disk, needle ose, hot palette, bunsen lamp, blender, balance, blade, 
micropipette, a gas stove, a set of glasses, a set of steam distillation, and Gas Chromatography-Mass Spectroscopy (GC-MS).

\section{Procedure}

\section{Sample Preparation}

Jeringau rhizome were collected and cleaned, then cut into small pieces. After that, extraction of essential oils were carried out.

\section{Extraction of essential oil in the rhizome Jeringau}

A total of $10 \mathrm{~kg}$ of jeringau rhizomes was extracted using steam distillation method. This process produced a mixture of oil and water, and then they were separated with a separating funnel. If emulsion was formed, $\mathrm{NaCl}$ was added. The oil phase was added $\mathrm{CaCl}_{2}$ anhydrous then decanted, while the water phase was added $\mathrm{NaCl}$ to separate the possibility of the presence of oil. The oils were then stored for identification and testing of antimicrobial compounds.

\section{Identification of Essential Oils by GC-MS}

The compounds of essential oil were analyzed by GC-MS, MS fragmentation was identified with the compounds in the database.

\section{Test antifungal activity of essential oils rhizome Jeringau}

Antifungal activity test of essential oils against pathogenic fungi (C. albicans) was done by well diffusion methods. Petri already containing $10 \mathrm{~mL}$ of NA media and $200 \mu \mathrm{L}$ of suspension of the fungus was allowed to solidify. After the suspension was solid, the diffusion wells were made using a cork borer, each well was filled with $20 \mu \mathrm{L}$ of the oils. The Petri was then incubated at a temperature of 37 ${ }^{\circ} \mathrm{C}$ for 48 hours, then calculated the diameter of inhibition zone.

Determination of Minimum Inhibitory Concentration (MIC) was conducted by the well diffusion method with multiple concentrations were: 0 (control), 0.2 , $0.4,0.8,1.0,2.0,3.0,4.0,5.0$, and $10.0 \%$. Test antifungal activity against the formation biomass was carried out according to methods conducted Rita et al. (2016) [7].

The antifungal activity test against the formation of biomass was done by dissolving the mushrooms with water to form a suspension of the fungus. The suspension was filtered with Whatman filter paper no. 2, so the spores will pass through and then collected in a glass beaker. One milliliter of spore suspension and the oils were put into Potato Dextro Broth (PDB) media. concentration of each oils given was 0 (control), $0.5 ; 1.0 ; 2.0 ; 4.0$; and $5.0 \%$. The final volume of the mixture was $100 \mathrm{~mL}$. Each treatment was repeated three times.

Incubation was performed for eight days, then the solution was centrifuged at $5,000 \mathrm{rpm}$ for 5 minutes. The precipitate obtained was dried at $60{ }^{\circ} \mathrm{C}$ until its weight was constant. Biomass subsequently was weighed and compared to the weight of the untreated fungal biomass extracts (control). Effect of isolates with different concentrations was designed with a completely randomized design and analyzed using Analysis of Variance, followed by a different test using Duncan's Multiple Range Test at the 5\% level. Inhibition of the formation of biomass was calculated by equation 1 [7].

$D H(\%)=\frac{B K-B P}{B K} X 100 \%$

\section{RESULTS AND DISCUSSION}

\section{A. Results}

Extraction of $10 \mathrm{~kg}$ rhizomes of jeringau produced $16.53 \mathrm{~mL}$ essential oil with a yield of $0.1653 \%$ ( $\rho=1.066$ ), the oil was brownish yellow and very flavorful. The compounds of the oil were analyzed by GC-MS, it was detected 12 peaks with a retention time (tR) and abundance (\%) presented in Table 1, while the chromatogram was presented in Figure 1.

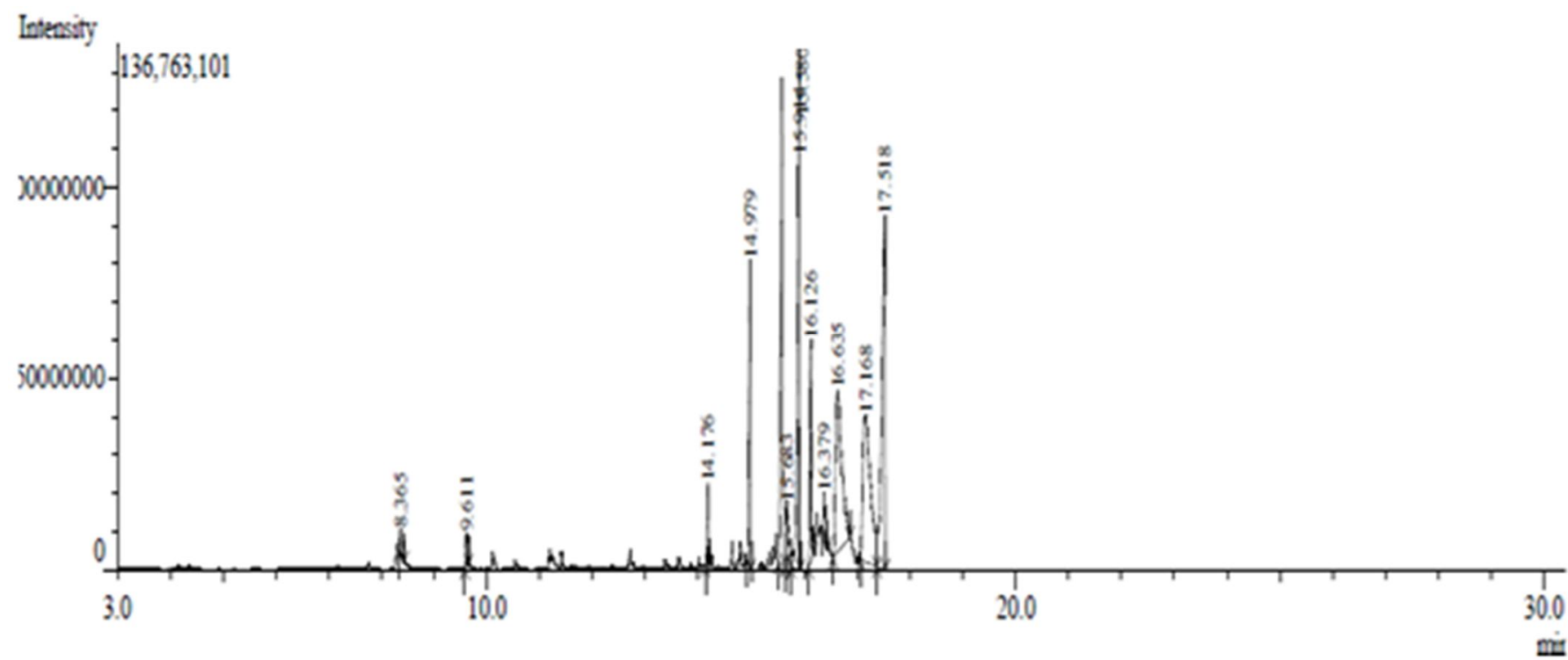

Figure 1. Gas Chromatography chromatograms of Essential Oil of Jeringau Rhizome (A. calamus Linn.) 
Table 1. GC Chromatogram of Essential Oil of Jeringau Rhizome (Acorus calamus Linn.)

\begin{tabular}{cccc}
\hline No & Peaks & $\begin{array}{c}\text { Retention Time } \\
\text { (Minute) }\end{array}$ & $\begin{array}{c}\text { Abundance } \\
(\boldsymbol{\%})\end{array}$ \\
\hline 1 & Peak1 & 8.366 & 3.73 \\
2 & Peak 2 & 9.611 & 1.07 \\
3 & Peak 3 & 14.177 & 1.15 \\
4 & Peak 4 & 14.978 & 7.68 \\
5 & Peak 5 & 15.580 & 7.97 \\
6 & Peak 6 & 15.680 & 0.93 \\
7 & Peak 7 & 15.908 & 7.77 \\
8 & Peak 8 & 16.127 & 2.61 \\
9 & Peak 9 & 16.380 & 3.34 \\
10 & Peak 10 & 16.642 & 26.84 \\
11 & Peak 11 & 17.167 & 18.62 \\
12 & Peak 12 & 17.518 & 18.29 \\
\hline
\end{tabular}

Table 2. The antifungal activity test of essential oils with varying concentrations toward $C$. albicans

\begin{tabular}{ccc}
\hline No. & $\begin{array}{c}\text { Oil Concentration } \\
(\%)\end{array}$ & $\begin{array}{c}\text { Inhibition zone } \\
(\mathrm{mm})\end{array}$ \\
\hline 1 & 0 & 0 \\
2 & 0.2 & 0 \\
3 & 0.4 & 0 \\
4 & 0.8 & $0 \mathrm{a}$ \\
5 & 1 & $7.83 \mathrm{~b}$ \\
6 & 2 & $9.10 \mathrm{c}$ \\
7 & 3 & $10.07 \mathrm{~d}$ \\
8 & 4 & $10.27 \mathrm{~d}$ \\
9 & 5 & $10.27 \mathrm{~d}$ \\
10 & 10 & $11.23 \mathrm{e}$ \\
\hline
\end{tabular}

* Values followed by the same letters in the same column are not significantly different according to the Duncan's Multiple Range Test at $P<5 \%$.
Each peak of GC chromatogram was then identified by using Mass Spectrometer and analyzed based on the database approach. The oils then test the antifungal activity against $C$. albicans.

The essential oils could inhibit the growth of $C$. albicans with a strong inhibition $(11 \mathrm{~mm})$. Antifungal test to determine the minimum inhibitory concentration (MIC) was performed at concentrations of 0 (control); 0.2; 0.4; ; $0.8 ; 1 ; 2 ; 3 ; 4 ; 5$; and $10 \%$. Results are presented in Table 2 . The result of antifungal activity test against the formation of biomass was presented in Table 3 .

Table 3. Inhibitory activity of essential oil of jeringau rizhome against biomass of Fusarium solani at 8 days of incubation in medium PDB

\begin{tabular}{cccc}
\hline No & $\begin{array}{c}\text { Oil } \\
\text { Concentration } \\
(\%)\end{array}$ & $\begin{array}{c}\text { Dry weight of } \\
\text { biomass } \\
(\mathrm{mg})\end{array}$ & Inhibition \\
\hline 1 & 0 & $4.47^{\mathrm{a}}$ & - \\
2 & 0.5 & $3.09^{\mathrm{b}}$ & 30.87 \\
3 & 1.0 & $2.35^{\mathrm{c}}$ & 47.43 \\
4 & 2.0 & $1.57^{\mathrm{d}}$ & 64.88 \\
5 & 4.0 & $1.35^{\mathrm{e}}$ & 69.80 \\
6 & 5.0 & $1.33^{\mathrm{e}}$ & 70.25 \\
\hline
\end{tabular}

* Values followed by the same letters in the same column are not significantly different according to the Duncan's Multiple Range Test at $P<5 \%$.

\section{B. Discussion}

Based on the MS database approach, the compounds of essential oils could be identified. The name and the group of the compound can be seen in Table 4, while the structure of the compounds was presented in Figure 2.

Table 4. The compounds of essential oil of jeringau rhizome (A. calamus Linn.) based database approach (NIST08s LIB)

\begin{tabular}{|c|c|c|c|c|c|c|}
\hline No & Peaks & $\begin{array}{c}\text { Retention Time } \\
\text { (Minute) }\end{array}$ & $\begin{array}{c}\text { Abundance } \\
(\%)\end{array}$ & $\mathbf{M}^{+}$ & Compound Name & Group \\
\hline 1 & Peak1 & 8.366 & 3.73 & 136 & (E)-3,7 dimethyl-1,3,6-Octatriene & Monoterpene \\
\hline 2 & Peak 2 & 9.611 & 1.07 & 154 & Linalool & Monoterpene \\
\hline 3 & Peak 3 & 14.177 & 1.15 & 204 & $\beta$-elemene & Sesquiterpene \\
\hline 4 & Peak 4 & 14.978 & 7.68 & 178 & Trans-methyl-iso-eugenol & Monoterpene \\
\hline 5 & Peak 5 & 15.580 & 7.97 & 220 & Shyobunone & Sesquiterpene \\
\hline 6 & Peak 6 & 15.680 & 0.93 & 204 & Bicyclo- germakrene & Sesquiterpene \\
\hline 7 & Peak 7 & 15.908 & 7.77 & 220 & Shyobunone & Sesquiterpene \\
\hline 8 & Peak 8 & 16.127 & 2.61 & 220 & Dehydroxy-iso-calamendiol & Sesquiterpene \\
\hline 9 & Peak 9 & 16.380 & 3.34 & 200 & $\alpha$-calacorene & Monoterpene \\
\hline 10 & Peak 10 & 16.642 & 26.84 & 208 & Euasarone & Monoterpene \\
\hline 11 & Peak 11 & 17.167 & 18.62 & 208 & Cis-asarone & Monoterpene \\
\hline 12 & Peak 12 & 17.518 & 18.29 & 208 & Trans-asarone & Monoterpene \\
\hline
\end{tabular}


<smiles>C=CC(C)=CCC=C(C)C</smiles>

(E)-3,7 dimethyl-1,3,6-Octatriene (trans- $\beta$-Ocimene) $(3.73 \%)$<smiles>C/C=C/c1ccc(O)c(OC)c1</smiles>

Trans-methyl-iso-eugenol (7.68\%)<smiles>C=C1CCC2C(C)CC=C(C(C)C)C2(O)C1</smiles>

Dehydroxy-iso-calamendiol (2.61\%)<smiles>C/C=C\C1C[C@H](OC)[C@](COC)(OC)C[C@H]1OC</smiles>

Cis-asarone $/ \beta$-asarone $(18.62 \%)$<smiles>C=CC(C)(O)CCC=C(C)C</smiles>

Linalool (1.07\%)<smiles>C=CC1(C)CCC(C(C)C)C(=O)C1C(=C)C</smiles>

Shyobunone (15.74\%)<smiles>CC1=CCC(C(C)C)c2cc(I)ccc21</smiles>

$\alpha$-calacorene (3.34\%)<smiles>CC=Cc1cc(OC)c(OC)cc1OC</smiles>

Trans-asarone/ $\alpha$-asarone (18.29\%)<smiles>C=C(C)C1CCC2(C)CCCC1C2C(=C)C</smiles>

$\beta$-elemene (1.15\%)

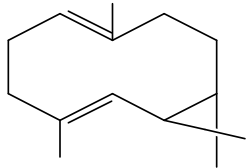

Bicyclo- germakrene (0.93\%)<smiles>COc1cc(OC)c(C(C)C)cc1OC</smiles>

Euasarone (26.84\%)

Figure 2. The structure of compounds in the essential oil of jeringau rhizome

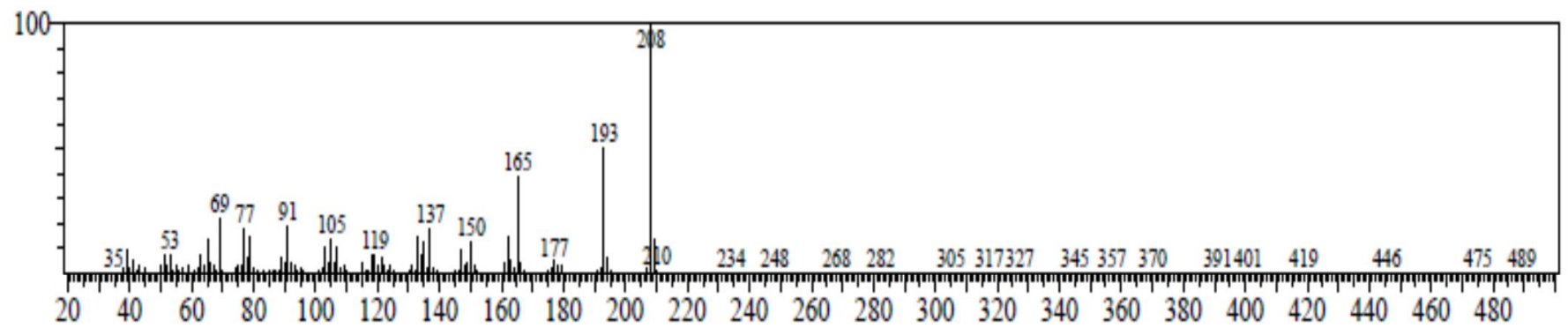

Hitt:1 Entry.17586 Library:MIST08.LIB

SI:96 Formula:C12H1603 CAS:2883-98-9 MolWeight:208 RetIndex:1568

CompName:Asarone \$ (E)-2,4,5-Trimethoxypropenylbenzene \$\$ trans-2,4,5-Trimethoxypropenyibenzene \$\$ Benzene, 1,2,4-trimethoxy-5-(1-propenyl)-, (I

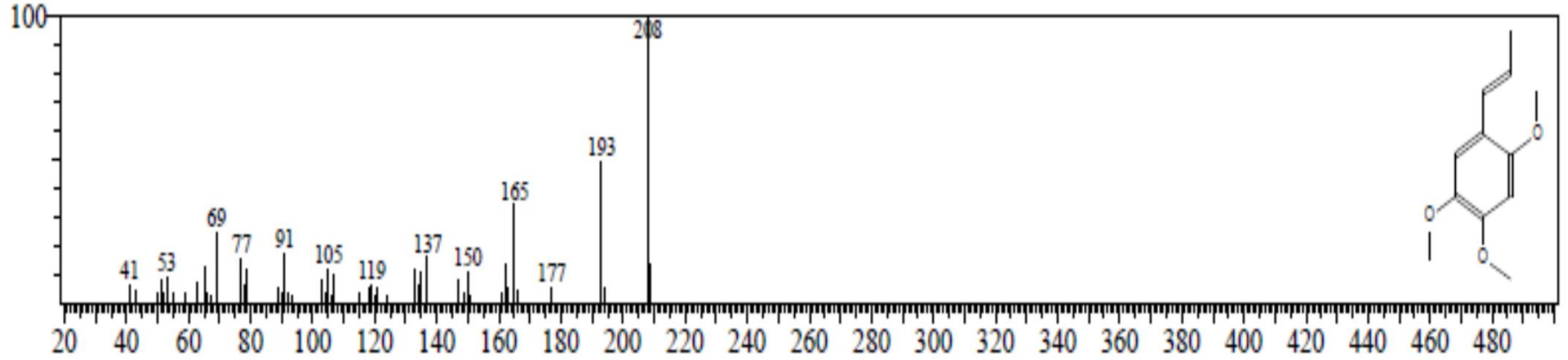

Figure 3. The fragmentation of asaron on MS spectra

Table 1 and Figure 1 showed that there were 12 peaks in the GC chromatogram, but based on the data base (Table 4), peaks 5 and 7 were the same compound that was Shyobunon, so the number of compounds in the essential oil was 11 compounds. The main content in the oil was asarone (both cis and trans) with total abundance of
$36.91 \%$. Fragmentation of asarone compared with data base could be seen in Figure 3. Spectrum asarone has a molecular ion $\left(\mathrm{M}^{+)}\right.$of 208 , the alleged fragmentation was presented in Figure 4. 


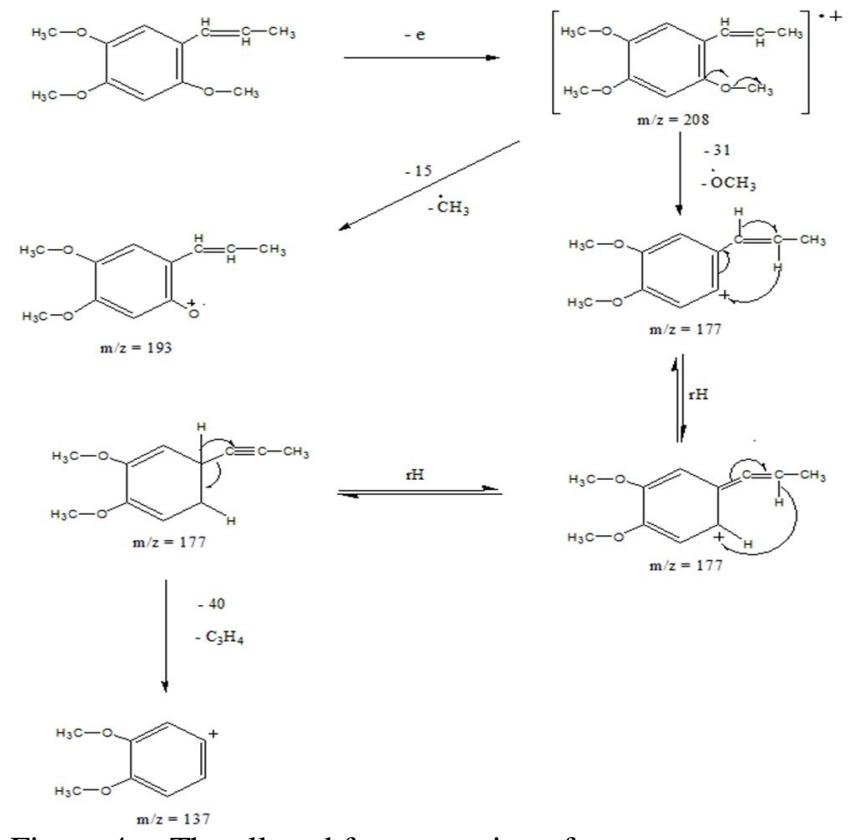

Figure 4. The alleged fragmentation of asarone

According Shenvi et al. (2011), asarone, especially $\beta$-asarone, have antifungal activity against several plant pathogenic fungi [9]. Asha and Ganjewala (2009) also reported that the roots and leaves of A. calamus $\mathrm{L}$. containing asarone have antimicrobial activity [2]. Phongpaichit (2005) reported that the asarone on jeringau has strong inhibitory activity towards Trichophyton rubrum, Microsporum gypseum, and Penicillium marneffe $i$ with $\mathrm{IC}_{50}$ values of $0.2 ; 0.2$; and $0.4 \mathrm{mg} / \mathrm{mL}$ respectively [6].

Antifungal activity test of the essential oil of jeringau rizhome showed that the oil could inhibit the growth of $C$. albicans with the inhibition of $11 \mathrm{~mm}$. According Ardiansyah (2005), if the inhibition was higher than $20 \mathrm{~mm}$ : the inhibition was very strong; $10-20 \mathrm{~mm}$ : strong inhibition; 5-10 mm: medium inhibition; and lower than $5 \mathrm{~mm}$ : weak inhibition. So it can be concluded that the essential oil of jeringau rhizomes could inhibit strongly the growth of $C$. albicans[1].

Table 2 showed that the inhibition of $C$. albicans growth increased with the increase of the oil concentration. At a concentration of $1 \%$, the oil was able to inhibit the growth of fungi with the inhibition zone of $7.83 \mathrm{~mm}$, while there was no inhibition zone with the lower of the oil concentration. So the minimum inhibitory concentration (MIC) of the oils to inhibit $C$ albicans was $1 \%$. The concentration of oil of 3,4 , and $5 \%$ showed no significant differences ( $\mathrm{p}<0.05)$ to inhibit the growth of $C$. albicans, with a strong inhibition between 10.07 to $10.27 \mathrm{~mm}$, so it can be said that the oil concentration of $3 \%$ was the optimum concentration in inhibiting the growth of $C$. albicans.

Based on Table 3, it can be seen that the inhibition of biomass $C$. albicans increased, or the amount of biomass decreased, with the increase of the essential oil concentration. At a concentration of $5.0 \%$, the dry weight of the biomass was not significantly different from the dry weight of the biomass at a concentration of $4 \%$. This showed that the oil concentration of $4 \%$ was the optimum concentration in inhibiting the formation of $C$. albicans biomass. The graph of correlation between the oil concentration and the inhibition of the formation of $C$. albicans biomass are presented in Figure 5.

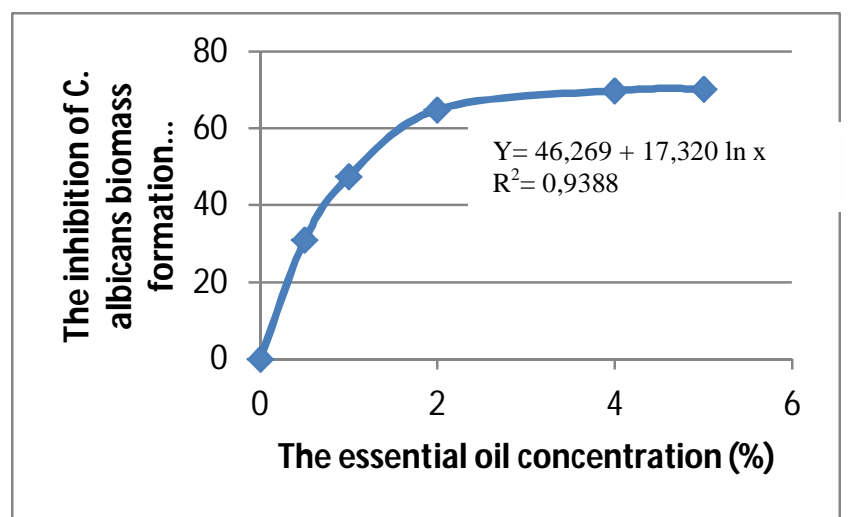

Figure 5. graph of correlation between the oil concentration and the inhibition of $C$. albicans biomass formation

Essential oils were a mixture of compounds which were terpenoid group consisting of monoterpenes and sesquiterpenes. Cowan (1999) reported that terpenoids have the ability to inhibit the growth of fungi by damaging the cell membrane so that the fungal growth was inhibited. Terpenoids reacted with porin (transmembrane protein) on the outer membrane of fungal cell wall to form a strong polymer bond so that it caused porin damage. Porin was able to transfer nutrients. When protein was broken it would reduce the permeability of fungal cell wall resulting in fungal cells would lack of nutrients, thus the growth of fungi was inhibited or die [3].

\section{CONCLUTION}

Based on the research results, it can be concluded that 1) The yield of volatile oil from rhizome of A. calamus L. was $0.1653 \%$, with density ( $\rho)$ of $1.066 \mathrm{~g} / \mathrm{mL}$. 2) Essential oils of the rhizome contained 11 compounds which asarone (cis and trans) was the major compound with a total abundance of $36.91 \%$. 3) The higher of the oil concentration, the stronger of the inhibition of growth and total biomass of $C$. albicans. 4) Minimum Inhibitory Concentration (MIC) of the oil to inhibit $C$. albicans was $1 \%$.

\section{ACKNOWLEDGEMENTS}

Authors would like to thanks to the Udayana University through the Institute of Research and Community Service which has provided research grant to support this study.

\section{REFERENCES}

[1] Astuti Ardiansyah (2005) Leaves Beluntas as Materials of Antibacterial and Antioxidant. "Daun Beluntas sebagai Bahan Antibakteri dan Antioksidan". Available at: http://www.berita_iptek.com/ cetak_ beritahp? kat=berita \&id=33. [accessed October 27, 2007]. 
[2] Asha, D.S., Ganjewala, D. (2009). Antimicrobial activity of Acorus calamus (L.) rhizome and leaf extract, Acta Biol. Szeg. 53 (1), pp. 45-49.

[3] Cowan, M.M. (1999) Plant Product as Antimicrobial Agents, Miamy University, Oxford.

[4] Kokare, C. R. (2007) Pharmaceutical Microbiology Principles and Applications. Nirali Prakashan.

[5] Pakasi, S.E. dan Salaki, C.L. (2013) Good Crop Cultivation of Karumenga (Acorus calamus). "Budidaya yang Baik Tanaman Karumenga (Acorus calamus)". Available at: https://seafast.ipb.ac.id/tpc-project/wp-content/...GAPKarumenga.pdf. [accessed April 5, 2015].

[6] Phongpaichit, S., Pujenjob, N., Rukachaisirikul, V. and Ongsakul, M. (2005) Antimicrobial activities of the crude methanol extract of Acorus calamus Linn. Songklanrimpangin J. Sci. Technol., 27(Suppl. 2), pp. 517-523.

[7] Rita, W.S., Asih, I.A.R.A, Yuliari, N.M. (2016) Potency of Jeringau rhizomes essential oil (Acorus calamus Linn.) as inhibitors of Fusarium solani, fungal pathogens causing stem rot diseases on the dragon fruit. "Potensi minyak atsiri rimpang jeringau (Acorus calamus Linn.) sebagai penghambat Fusarium solani, jamur patogen penyebab busuk batang pada buah naga". Cakra Kimia, 4(2), pp. 120-128.

[8] Setyolaksono, M. P. (2013) Jeringau, Herba With Myriad Benefits "Jeringau, Herba Dengan Segudang Manfaat". BBPPTP Ambon. Available at: http://ditjenbun.pertanian.go.id/ bbptpambon/berita280-jeringau-herba-dengan-segudang-manfaat.html [accessed April 20, 2015].

[9] Shenvi, S., Vinod, Hegde, R., Kush, A., Reddy, G. C. (2011) A unique water soluble formulation of $\beta$-asarone from sweet flag (Acorus calamus L.) and its in vitro activity against some fungal plant pathogens, Journal of Medicinal Plants Research, 5 (20), pp. 5132-5137.

[10] Venskutonis, P.R., and Dagilyte, A. (2003) Composition of Essential Oil of Sweet Flag (Acorus calamus L.) Leaves at Different Growing Phases. Journal of Essential Oil Research, 15(5): 313-318. Available at: http://www.tandfonline.com/doi/abs/10.1080/10412905.2003. 9698598\#.VNRt1iw6TIU [accessed April 5, 2015]. 